\title{
A ENFERMAGEM E O PROBLEMA DO USO E ABUSO DE ÁLCOOL E OUTRAS DROGAS
}

Angela Maria Mendes Abreu $^{1}$

0 fenômeno das drogas constitui hoje em dia uma verdadeira e urgente questão de saúde publica no mundo. É tratado como um problema social com impactos diretos na saúde do indivíduo, família, comunidade e sociedade em geral.

Pode ser compreendido em sua dimensão nacional e internacional com seus impactos na esfera global. Envolve o problema de produção, tráfico e comércio, assim como, o consumo das drogas lícitas e ilícitas nas Américas e no Mundo.

Os problemas originados das drogas são eminentemente complexos e dinâmicos. Assim, toma-se como pressuposto que as complexas relações que envolvem o uso e abuso de drogas lícitas e ilícitas constituem um cenário de vulnerabilidade a violência. Portanto, configura-se como um problema dos mais complexos e desafiantes enfrentados pelos governantes dos países desenvolvidos e principalmente dos países em desenvolvimento no mundo.

Álcool e drogas é um assunto que diretamente ou indiretamente, diz respeito a todos nós. Esse tema permite olhares sob várias perspectivas. Podemos apreciá-lo enquanto cidadãos de uma nação, membros de uma família, profissionais da saúde, como pesquisadores e docentes, bem como participantes de uma comunidade. Para cada uma delas justifica-se um engajamento pleno e indispensável. Dedicar-se a essa temática é tarefa de inquestionável relevância, pois exige responsabilidade, treinamento e, sobretudo conhecimento científico.

0 consumo excessivo e cada vez mais precoce de álcool e drogas é uma situação que preocupa não só o Brasil, mais também diversos países do mundo. A busca de estratégias para o enfrentamento dessa questão, tanto por parte do poder público quanto da sociedade, tem apontado para uma direção comum, a de centrar esforços no sentido de dar ao tema um tratamento realista, pragmático e que promova resultados efetivos.

É necessário centrar esforços para intensificar as relações com a sociedade e a comunidade científica. Nesse sentido, esse tema está sendo devidamente tratado nos Programas de Ensino e oferecido aos alunos, pelo corpo docente da Escola de Enfermagem Anna Nery, como um componente de saúde e como um problema social que atinge nossa sociedade e principalmente o desenvolvimento de nosso país.

Por isso parabenizo, mais uma vez, a Escola de Enfermagem Anna Nery, no âmbito da academia, realizando seu papel, no enfrentamento dessa temática, tão relevante nos dias atuais. E, através de sua revista apresenta, nessa edição especial, os problemas relacionados ao uso e abuso de álcool e outras drogas. Trás em voga e discute vários temas de contribuição científica, para divulgar o conhecimento e o entendimento desses estudos, nessa área, que hoje se apresenta como um dos mais relevantes e principais problemas de saúde publica no mundo, o consumo de álcool e outras drogas. 


\section{THE NURSNG AND THE PROBLEM OF USE AND ABUSE OF ALCOHOL AND OTHER DRUGS}

Angela Maria Mendes Abreu

The drugs phenomenon constitutes nowadays a true and urgent question of public health in the world. It is treated as a social problem with direct impact in the health of the individual, family, community and society in general.

It must be comprehended in its national and international dimension with its impact in the global sphere. It involves the problem of the production, traffic and business, as such as the consumption of licit and illicit drugs in the Americas and in the World.

The originated problems with the drugs are eminently complex and dynamical. Thus, it is taking as presuppose that the complexes relations that involves the use and abuse of licit and illicit drugs constitute scenery of vulnerability to the violence. Therefore, it configured as a one of the most complex and challenger problem faced by the government of the developed countries and mainly of the countries in development process in the world.

Alcohol and drugs it is a subject that directly or indirectly is about every one of us. This theme allows point of views under several perspectives. We may appreciate it as citizens of a nation, members of a family, health professionals, as researchers and teachers, as well as participants of a community. For each one of them it is justified a full and indispensable engagement. To dedicates itself to this theme it is a task of unquestionable importance, because it requires responsibility, training and, above all, scientific knowledge.

The excessive and more and more early consumption of alcohol and drugs it is a situation that preoccupy not only the Brazil, as also different countries of the world. The search of strategies to face this question, as much by the public power as by the society, it has been pointed towards a common direction, the one of to center efforts in the sense to give to the theme a realistic, pragmatic treatment and that promotes effectives results.

It is necessary to center efforts to intensify the relations with the society and the scientific community. In this sense, this theme has been treated properly in the Learning Programs and offered to the students, by the teaching staff of the Anna Nery School of Nursing, as a health component and as a social problem that affects our society and mostly the development of our Country.

For that I congratulate once more the Anna Nery School of Nursing, in the academic scope, doing its role, in the confrontation of this theme, so important nowadays. And, trough its Journal presents, in this special edition, the problems related to the use and abuse of alcohol and other drugs. It brings back to vogue and discuss several themes of scientific contribution, to spread the knowledge and the understanding of these studies, in this area, that today presents itself as one of the most relevant and important problem of public health in the world, the consumption of alcohol and other drugs. 


\section{LA ENFERMERÍA Y EL PROBLEMA DEL USO Y ABUSO DE ALCOHOL Y OTRAS DROGAS}

Angela Maria Mendes Abreu

El fenómeno de las drogas constituye hoy en día una verdadera y urgente cuestión de salud pública en el mundo. Es tratado como un problema social con impactos directos en la salud del individuo, familia, comunidad y sociedad en general.

Puede ser comprendido en su dimensión nacional e internacional con sus impactos en la esfera global. Envuelve el problema de producción, trafico y comercio, así como, el consumo de las drogas licitas e ilícitas en las Américas y en el Mundo.

Los problemas originados de las drogas son eminentemente complejos y dinámicos. Así, se toma como presupuesto que las complejas relaciones que envuelvan el uso y abuso de drogas lícitas e ilícitas constituyen un escenario de vulnerabilidad la violencia. Por lo tanto, se configura como un problema de los más complejos y desafiantes enfrentados por los gobernantes de los países desarrollados y principalmente de los países en desarrollo en el mundo.

Alcohol y drogas es un tema que directamente o indirectamente, dice respecto a todos nosotros. Ese tema permite miradas bajo muchas perspectivas. Lo podemos apreciar como ciudadanos de una nación, miembros de una familia, profesionales de la salud, como investigadores y docentes, bien como participantes de una comunidad. Para cada una de ellas justificase una articulación plena e indispensable. Dedicarse a ese tema es tarea de incuestionable importancia, pues exige responsabilidad, entrenamiento y sobre todo conocimiento científico.

El consumo excesivo y cada vez más precoz de alcohol y drogas es una situación que preocupa no solamente el Brasil, más también muchos países del mundo. La búsqueda de estrategias para el enfrentamiento de esa cuestión, tanto por parte del poder público cuanto de la sociedad, tiene apuntado para una dirección común, la de centrar esfuerzos en el sentido de dar al tema un tratamiento realista, pragmático y que promueva resultados efectivos.

Es necesario centrar esfuerzos para intensificar las relaciones con la sociedad y la comunidad científica. En ese sentido, ese tema está siendo debidamente tratado en los Programas de Enseñanza y ofrecido a los alumnos, por el cuerpo docente de la Escuela de Enfermería Anna Nery, como un componente de salud y como un problema social que atinge nuestra sociedad y principalmente el desarrollo de nuestro país.

Por eso felicito, más una vez, la Escuela de Enfermería Anna Nery, realizando su papel en el ámbito de la academia, en el enfrentamiento de esta temática, tan relevante en los días actuales. Y, a través de su revista presenta, en esa edición especial, los problemas relacionados al uso y abuso de alcohol y otras drogas. Trae en boga y discute muchos temas de contribución científica, para divulgar el conocimiento y el entendimiento de eses estudios, en esa área, que hoy se presenta como uno de los más relevantes y principales problemas de salud pública en el mundo, el consumo de alcohol y otras drogas. 